\title{
STUDI TENTANG KEMUNGKINAN PEMANFAATAN PENDIDIKAN JARAK JAUH UNTUK PENGEMBANGAN SDM KEPALA SEKOLAH MADRASAH
}

Oleh: Waldopo

\section{Abstrak}

Departemen Agama melalui MESA (Madrasah Education Sub Sector Assesment) melakukan studi menyeluruh tentang pengelolaan Madrasah sekaligus melihat kesiapan Madrasah jika pengelolaannya diserahkan ke daerah dengan mengkaji berbagai dokumen, mewawancarai para guru dan Kepala Madrasah, pakar, pejabat, praktisi lapangan, melakukan diskusi kelompok terfokus (Focus Group Discussion) dengan para pejabat Propinsi dan Kabupaten/Kota Departemen Agama dan yang membidangi anggaran dan perencanaan di 6 lokasi sampel (Jambi, Sumatera Barat, Jawa Timur, Kalimantan Selatan, Bali, dan Sulawesi Tenggara) guna melihat kondisi realitas Madrasah. Selain itu, dilakukan juga observasi dan wawancara dengan para pengelola MDC (Madrasah Development Center) dan CLRC (Community Learning Resources Center) dan pengelola Madrasah Model. Tulisan ini difokuskan pada pengembangan SDM Kepala Madrasah sesuai dengan fungsinya yang sangat penting dalam menentukan keberhasilan kegiatan pembelajaran/pendidikan di Madrasah. Hasil penelitian menunjukkan bahwa dari 37.288 Kepala Madrasah, lebih dari separuhnya (19.210) berstatus masih non pegawai negeri. Dari segi pendidikan, sebagian besar dari mereka belum berkualifikasi pendidikan S1. Selain itu, para pejabat Depag di daerah cenderung merasa "belum siap" jika Madrasah didesentralisaikan sebagaimana halnya dengan sekolah umum.

Kata Kunci: $\quad$ Community Learning Resources Center (CLRC), Madrasah Development Center (MDC), Madrasah Model, MESA,

\section{PENDAHULUAN}

Pembangunan Sumber Daya Manusia (SDM) dalam kaitannya dengan usaha untuk memperoleh hasil pendidikan dan pembelajaran yang berkualitas, tidak terlepas dari peran Kepala Sekolah (school principals), di samping komponen-komponen pendidikan lainnya. Mengingat besarnya peranan kepala sekolah dalam mengendalikan terjadinya kegiatan pembelajaran, maka Kepala Sekolah dipilih untuk dijadikan fokus dalam tulisan ini.
Peranan Kepala Sekolah dianggap sangat dominan dalam menentukan hasil pendidikan/pembelajaran di Madrasah, karena merekalah yang mengatur, menetapkan dan sekaligus mengendalikan terjadinya kegiatan pendidikan/ pembelajaran di Madrasah. Kalau diinginginkan adanya hasil pendidikan/ pembelajaran yang berkualitas dari Madrasah, maka SDM Kepala Sekolah juga harus yang berkualitas disamping SDM lainnya seperti Guru misalnya.

*) Drs. Waldopo, M.Pd, adalah peneliti pada bidang Teknologi Pembelajaran Pusat Teknologi Informasi dan Komunikasi Pendidikan Departemen Pendidikan Nasional, konsultan untuk MESA Tahun 2003 (Madrasah Educations Subsector Assessment) Departemen Agama bidang pengembangan Sumber Daya Manusia. 
Dalam kaitannya dengan pendidikan di Madrasah, sesuai dengan Keppres No.34/ 1972, Inpres No.15/1974 dan Surat Keputusan Bersama Tiga Menteri yaitu Mendikbud (pada waktu itu), Menag dan Mendagri Nomor 0371 U/1975 dan No 16 tahun 1975 tanggal 24 Maret 1975, Madrasah merupakan bagian integral dari sistem pendidikan nasional. Hal ini ditegaskan kembali dalam Undang Undang Sistem Pendidikan Nasional Nomor 2 tahun 1989. Dalam Undang-Undang tersebut kedudukan Madrasah sama dengan sekolah umum dengan tambahan yang berciri khas Islam. Dengan demikian, Madrasah Ibtida'iyah (MI) kedudukannya sama dengan Sekolah Dasar, Madrasah Tsanawiyah (M.Ts) sama dengan SMP dan Madrasah 'Aliyah (MA) sama dengan Sekolah Menengah Atas (SMA). Dalam Undang-Undang Nomor 20 tahun 2003 tentang Sistem Pendidikan Nasional bab VI pasal 17 ayat 2 ditegaskan bahwa Pendidikan Dasar berbentuk Sekolah Dasar (SD), Madrasah Ibtida'iyah (MI) atau bentuk lain yang sederajat serta Sekolah Menengah Pertama (SMP) dan Madrasah Tsanawiyah (M.Ts) atau bentuk lain yang sederajat. Selanjutnya pada bab yang sama pasal 13 ayat 3 disebutkan Pendidikan Menengah berbentuk Sekolah Menengah Atas (SMA), Madrsah 'Aliyah (MA), Sekolah Menengah Kejuruan (SMK) dan Madrasah 'Aliyah Kejuruan (MAK) atau bentuk lain yang sederajat. Dengan demikian pada saat ini Madrasah kedudukannya benar-benar diakui sama dengan sekolah Umum (MI sederajat dengan SD, MTs sederajat dengan SMP, dan MA sederajat dengan SMA). Madrasah merupakan salah satu Subsistem Pendidikan Nasional. Sebagai salah satu subsistem pendidikan nasional Madrasah dituntut untuk menyampaikan materi pendidikan (kurikulum) yang sama dengan sekolah-sekolah umum yang selama ini dikelola Depdiknas. Oleh karena itu, kurikulum yang digunakan Madrasah pada saat ini haruslah sama dengan kurikulum yang digunakan oleh sekolah-sekolah umum yaitu kurikulum 2004 yang berbasis kompetensi (KBK).dan selanjutnya disesuaikan dengan Kurikulum pada Tingkat Satuan Pendidikan (KTSP). Meski demikian Madrasah juga tidak boleh melupakan ciri khasnya sebagai lembaga pendidikan yang mengajarkan materi-materi keagamaan Islam. Ciri khas inilah sebenarnya yang merupakan nilai plus dari Madrasah pada saat ini. Berdasarkan ciri khasnya tersebut, maka secara substansial dapat dikatakan bahwa tujuan pendidikan Madrasah selain sama dengan sekolah umum, juga mempunyai tujuan tambahan yaitu untuk menghasilkan insan-insan intelek yang bukan hanya sekedar menguasai pengetahuan umum, namun juga menguasai materi-materi keagamaan Islam. Madrasah ingin mendidik siswa-siswanya menjadi manusia-manusia pandai (dalam bidang pengetahuan umum) yang berwawasan Islam (Islami). Keislaman mereka diharapkan bukan hanya tercermin dalam pola fikirnya namun juga dalam tingkah lakunya sehari-hari. Dengan demikian, dapat disimpulkan bahwa beban kurikulum yang harus disampaikan oleh Madrasah jauh lebih berat jika dibandingkan dengan sekolah umum.

Sehubungan dengan beban kurikulum yang jauh lebih berat tersebut, sudah sewajarnya jika Madrasah harus didukung oleh tenagatenaga Kepala Sekolah handal, artinya memiliki kualifikasi akademis yang memenuhi persyaratan serta memiliki kompetensi yang dapat mengelola dan mengkoordinir kegiatan pembelajaran yang dilaksanakan oleh para Guru secara baik. Disamping itu Kepala Sekolah juga harus bisa menjadi teladan yang baik bagi para Guru, tenaga administratif maupun siswa-siswanya. Itulah gambaran riil yang seharusnya dimiliki oleh Kepala Madrasah. Mengingat beratnya beban tersebut, maka sudah sewajarnya jika Kepala Madrasah memperoleh penghargaan yang lebih tinggi jika dibandingkan dengan Kepala Sekolah umum.

\section{KAJIAN TEORI}

Berbicara tentang perjalanan Madrasah hingga menjadi bagian dari subsistem pendidikan nasional; tidak bisa terlepas dari sejarah masukknya Islam ke Indonesia. Islam masuk ke Indonesia diperkirakan sudah dimulai pada abad ke 7 Masehi melalui interaksi antara penduduk pribumi dengan para pedagang muslim dari kawasan Gujarat 
(India) yang sengaja datang ke Indonesia untuk berda'wah sambil berdagang. Disamping itu, masuknya Islam ke Indonesia juga dibawa oleh para sufi yang sengaja melakukan perjalanan dengan tujuan untuk berda'wah (menyebarkan Agama Islam). Islam masuk ke Indonesia secara pesat dimulai pada abad ke 12 Masehi (Journal Madrasah, 1996 : 10). Perkembangan selanjutnya para tokoh muslim (yang rata-rata juga sebagai da'i) melakukan penyebaran agama Islam. Disamping berdakwah secara langsung kepada masyarakat, mereka juga berdakwah melalui pendirian pesantrenpesantren dan sekolah-sekolah yang disebut Madrasah. Pada awalnya Madrasah didirikan khusus untuk mengajarkan bebagai pengetahuan tentang agama Islam serta ilmu 'alat yang diperlukan untuk memahaminya seperti bahasa Arab dan lain-lain. Hampir seluruh Madrasah ketika itu dikelola secara swasta oleh masyarakat. Pemerintah mulai ikut terlibat dalam pengelolaan pendidikan Madrasah semenjak didirikan Departemen Agama 3 Januari 1946, meskipun departemen ini embrionya sudah ada sejak zaman Belanda dengan berdirinya kantor Voor Inlandcshe en Mohammadensche Zaken (Journal Madrasah, 1996 : 11). Dengan keterlibatannya tersebut pemerintah secara berangsur-angsur memasukkan kurikulum umum ke dalam pendidikan Madrasah. Dengan demikian lulusan pendidikan Madrasah diharapkan disamping memiliiki pengetahuan di bidang agama Islam juga memiliiki pengetahuan di bidang ilmu pengetahuan dan teknologi secara umum. Selanjutnya Pendidikan Madrasah diharapkan akan menjadi bagian dari sistem pendidikan nasional yang menghasilkan SDM-SDM yang berkualitas. Seiring dengan perjalanan waktu, perkembangan dan kemajuan-kemajuan yang dicapai oleh pendidikan Madrasah, maka pada era tahun tujuhpuluhan pemerintah memeberikan appresiasi. Sesuai dengan Keppres No.34/ 1972, Inpres No.15/1974 dan Surat Keputusan Bersama Tiga Menteri yaitu Menteri Pendidikan dan Kebudayaan (pada waktu itu), Menteri Agama dan Menteri Dalam Negeri Nomor 0371 U/1975 dan No 16 tahun 1975 tanggal 24 Maret 1975, Madrasah merupakan bagian integral dari sistem pendidikan nasional. Hal ini ditegaskan kembali dalam Undang Undang Sistem Pendidikan Nasional Nomor 2 tahun 1989. Dalam Undang-Undang tersebut kedudukan Madrasah sama dengan sekolah umum dengan tambahan yang berciri khas Islam. Dengan demikian, Madrasah Ibtida'iyah (MI) kedudukannya sama dengan Sekolah Dasar (SD), Madrasah Tsanawiyah (M.Ts) sama dengan Sekolah Menengah Pertama (SMP) dan Madrasah 'Aliyah (MA) sama dengan Sekolah Menengah Atas (SMA). Dalam Undang-Undang Nomor 20 tahun 2003 tentang Sistem Pendidikan Nasional bab VI pasal 17 ayat 2 ditegaskan bahwa Pendidikan Dasar berbentuk Sekolah Dasar (SD), Madrasah Ibtida'iyah (MI) atau bentuk lain yang sederajat serta Sekolah Menengah Pertama (SMP) dan Madrasah Tsanawiyah (M.Ts) atau bentuk lain yang sederajat. Selanjutnya pada bab yang sama pasal 13 ayat 3 disebutkan Pendidikan Menengah berbentuk Sekolah Menengah Atas (SMA), Madrasah 'Aliyah (MA), Sekolah Menengah Kejuruan (SMK) dan Madrasah 'Aliyah Kejuruan (MAK) atau bentuk lain yang sederajat. Dengan demikian pada saat ini Madrasah kedudukannya benar-benar diakui sama dengan sekolah Umum (MI sederajat dengan SD, MTs sederajat dengan SMP, MA sederajat dengan SMA dan MAK sederajat dengan SMK). Madrasah benar-benar merupakan salah satu Subsistem Pendidikan Nasional. Sebagai salah satu subsistem pendidikan nasional. Madrasah dituntut untuk menyampaikan materi pendidikan (kurikulum) yang sama dengan sekolah-sekolah umum yang selama ini dikelola Departemen Pendidikan Nasional (Depdiknas). Oleh karena itu, kurikulum yang digunakan Madrasah juga harus sama dengan kurikulum yang digunakan oleh sekolah-sekolah umum yaitu kurikulum tahun 1994 atau kurikulum 2004 yang berbasis kompetensi (KBK) yang kemudian disesuaikan dengan Kurikulum Tingkat Satuan Pendidikan (KTSP). Meski demikian Madrasah juga tidak boleh melupakan ciri khasnya sebagai lembaga pendidikan yang mengajarkan materi-materi keagamaan Islam. Ciri khas inilah sebenarnya yang merupakan nilai plus dari Madrasah pada saat ini. Berdasarkan ciri khasnya tersebut, maka secara substansial 
dapat dikatakan bahwa tujuan pendidikan Madrasah selain sama dengan sekolah umum juga harus mempunyai tujuan tambahan yaitu untuk menghasilkan insaninsan intelek yang bukan hanya sekedar menguasai pengetahuan dan teknologi yang sifatnya umum, namun juga harus menguasai materi-materi keagamaan Islam. Madrasah ingin mendidik siswa-siswanya menjadi manusia-manusia pandai (dalam bidang pengetahuan umum) yang berwawasan Islam (Islami). Keislaman mereka diharapkan bukan hanya tercermin dalam pola fikirnya namun juga dalam tingkah lakunya sehari-hari. Dengan demikian, dapat disimpulkan bahwa beban kurikulum yang harus disampaikan oleh Madrasah jauh lebih berat jika dibandingkan dengan beban kurikulum pada sekolah umum.

Sehubungan dengan beban kurikulum yang jauh lebih berat tersebut, sudah sewajarnya jika Madrasah harus dipimpin oleh tenagatenaga Kepala Sekolah handal, artinya memiliki kualifikasi dan kompetensi, memenuhi persyaratan akademis dan dapat menjadi teladan yang baik bagi para guru dan siswa-siswanya. Itulah gambaran riil kepala sekolah yang seharusnya dimiliki oleh Madrasah. Mengingat beratnya beban tersebut, maka sudah sewajarnya jika Kepala Madrasah memperoleh penghargaan yang lebih tinggi jika dibandingkan dengan Kepala Sekolah umum.

Mengenai penerapan sistem Pendidikan Jarak Jauh (PJJ) untuk kegiatan pendidikan/ pembelajaran dinilai memiliki beberapa kelebihan antara lain: murah, memiliki daya jangkau yang luas serta peserta didiknya dapat mengikuti kegiatan pembelajaran dengan tanpa harus meninggalkan tempat tugasnya.

Pendidikan Jarak Jauh yang sering juga disebut "Distance Learning", atau "Open Learning", atau "Independent Study", atau "Self Directed Learning", atau "Virtual Learning" dan lain-lain merupakan sistem pendidikan yang mana peserta didiknya terpisah dengan pendidik. Kegiatan pembelajarannya bersifat mandiri dengan menggunakan berbagai sumber belajar, baik yang dapat diakses melalui ICT maupun sumber - sumber belajar yang lainnya.

Dalam Sistem pendidikan jarak jauh peserta didik dituntut untuk bisa belajar secara mandiri, artinya dengan memanfaatkan berbagai sunber yang ada, peserta didik diharapkan dapat mencari sendiri berbagai informasi, pengetahuan ataupun keterampilan yang mereka butuhkan untuk mencapai tujuan pembelajaran. Oleh karena itu peserta didik benar-benar dituntut untuk dapat mendisiplinkan diri-sendiri, mengatur dirinya sendiri, jujur pada dirinya sendiri dan lain-lain sehingga kegiatan pembelajaran yang sedang mereka laksanakan dapat berjalan secara effektif dan effisien. Dengan perkembangan teknologi informasi dan komunikasi yang begitu pesat seperti sekarang ini peserta didik dapat belajar secara mandiri kapan saja dan di mana saja. Selain itu melalui dunia maya (internet) peserta didik dapat belajar apa saja sekaligus mendownload materi pembalajaran yang sedang mereka pelajari. Melalui dunia maya mereka juga bisa bertanya kepada para pakar yang ahli di bidangnya, baik pakar yang berasal dari dalam maupun luar negeri. Dengan demikian dapat dikatakan bahwa di era kemajuan teknologi informasi dan komunikasi seperti sekarang ini pendidikan jarak jauh merupakan suatu keniscaya-an. Dengan melimpahnya berbagi informasi (termasuk materi pambelajaran) yang beredar di jagad raya ini tidaklah berlebihan jika dikatakan bahwa orang bisa belajar apa saja, kapan saja dan di mana tanpa harus terikat ruang dan waktu serta keharusan bertemu dengan pendidik secara tatap muka setiap hari.

Secara lebih rinci dapat dikemukakan beberapa ciri Pendidikan Jarak Jauh sebagai berikut:

1. Antara pendidik dengan peserta didik bekerja secara terpisah sepanjang terjadinya proses pembelajaran. Ini berrati peserta didik harus dapat belajar secara mandiri.

2. Adanya lembaga pendidikan yang merancang dan menyiapkan bahan belajar, serta memberikan pelayanan bantuan belajar kepada peserta didik. 
3. Materi pembelajaran disampaikan kepada peserta didik melalui media pembelajaran seperti: media cetak, surat-menyurat, media radio, kaset audio, televisi, kaset video, komputer (baik yang bersifat on line/internet maupun off line/CAI, CD-Room) dan lainlain.

Media pembelajaran yang berupa radio, televisi dan internet disamping berfungsi untuk menyampaikan materi pembelajaran juga sebagai alat komunikasi antara pendidik dengan peserta didik.

4. Adanya usaha untuk terjadinya komunikasi dua arah antara peserta didik dengan pendidik, antara peserta didik dengan lembaga penyelenggara, atau antara sesama peserta didik. Inisiatif untuk berkomunikasi bukan hanya datang dari pendidik atau dari pihak lembaga penyelenggara, tetapi bisa juga datang dari peserta didik.

5. Dalam pendidikan jarak jauh tidak ada kelompok belajar yang sifatnya tetap, sepanjang masa belajarnya. Karena itu peserta didik mempelajari suatu materi pembelajaran secara individual bukan secara kelompok, meskipun secara pereodik ada pertemuan antara peserta didik yang sedang mempelajari bidang studi yang sama untuk membicarakan berbagai hal tentang pelajaran yang sedang mereka pelajari.

Ada beberapa keuntungan dengan diterapkannya pendidikan jarak jauh untuk menyelenggarakan kegiatan pendidkan (pengembangan SDM). Keuntungan tersebut antara lain:

1. Pemerintah/lembaga penyelenggara tidak harus membangun kelas baru, karena peserta didik dapat belajar dimana saja dan kapan saja.

2. Pemerintah/lembaga penyelenggara tidak harus mengangkat/menambah guru baru, karena pada prinsipnya peserta didik dapat memanfaatkan para guru/ para-pakar yang sudah ada. Baik pakar yang ada di lembaga penyelenggara maupun yang tersebar di dunia maya. Demikian pula dengan fasilitas ataupun infrastruktur pembelajaran lainnya. Peserta didik dapat memanfaatkan fasilitas ataupuan infrastruktur yang sudah ada.

3. Fleksibel. Artinya pendidikan jarak-jauh sewaktu-waktu bisa dibuka dan sewaktuwaktu juga bisa ditutup. Jika di suatu daerah membutuhkan, maka ia bisa dibuka. namun jika di daerah itu tidak membutuhkan lagi maka bisa ditutup dan bisa dibuka kembali jika dibutuhkan.

\section{HASIL KAJIAN DAN PEMBAHASAN}

Temuan-temuan di lapangan menunjukkan; bahwa selain Guru; Kepala Sekolah juga memiliki peran yang sangat dominan dalam menentukan keberhasilan sekolah (Kelompok Kerja Tenaga Kependidikan, 1999 : 80). Hal yang sama tentu juga akan berlaku di Madrasah, baik di Madrasah-Madrasah negeri maupun di Madrasah-Madrasah swasta. Dengan demikian Kepala Sekolah merupakan SDM yang harus dipersiapkan dengan sebaikbaiknya jika kita menginginkan Madrasah menghasilkan produk yang berkualitas baik ketika Madrasah dikelola oleh Depag Pusat maupun ketika Madrasah didesentralisasikan.

\section{Kondisi Kepala Sekolah} Berdasarkan Status Kepegawaian Secara nasional jumlah Kepala Madrasah ada 37.288 orang dengan perincian sebagai berikut (EMIS-DEPAG, Statistk Pendidikan Islam 2003)

Tabel 1. Status Kepegawaian Kepala Madrasah

\begin{tabular}{|l|c|c|c|}
\hline \multirow{2}{*}{ Jenis Madrasah } & \multicolumn{2}{|c|}{ Status Kepegawaian } & \multirow{2}{*}{ Jumlah } \\
\cline { 2 - 3 } & $\begin{array}{c}\text { Pegawai } \\
\text { Negeri }\end{array}$ & $\begin{array}{c}\text { Non Pegawai } \\
\text { Negeri }\end{array}$ & \\
\hline $\begin{array}{l}\text { Madrasah Ibtida'iyah } \\
\text { Negeri (MIN) }\end{array}$ & 1.482 & - & 1.482 \\
\hline $\begin{array}{l}\text { Madrasah Ibtida'iyah } \\
\text { Swasta (MIS) }\end{array}$ & 10.804 & 10.446 & 21.250 \\
\hline $\begin{array}{l}\text { Madrasah Tsanawiyah } \\
\text { Negeri (M Ts. N) }\end{array}$ & 1.165 & - & 1.165 \\
\hline $\begin{array}{l}\text { Madrasah Tsanawiyah } \\
\text { Swasta (M Ts. S) }\end{array}$ & 3.054 & 6.565 & 9.619 \\
\hline $\begin{array}{l}\text { Madrasah 'Aliyah } \\
\text { Negeri (MAN) }\end{array}$ & 577 & - & 577 \\
\hline $\begin{array}{l}\text { Madrasah 'Aliyah } \\
\text { Swasta (MAS) }\end{array}$ & 996 & 2.199 & 3.195 \\
\hline J u m I a h & 18.078 & 19.210 & 37.288 \\
\hline
\end{tabular}


Dari tabel 1 nampak bahwa seluruh Madrasah Negeri kepala sekolahnya berstatus pegai negeri. Hal ini merupakan sesuatu yang bagus. Namun secara keseluruhan jumlah Kepala Sekolah yang statusnya honorer masih lebih banyak.

Karena tuntutan Undang- undang, maka mau tidak mau Madrasah harus didesentralisasikan sebagaimana sekolah-sekolah lainnya. Sehubungan dengan hal itu, kini masih terdapat 19.210 orang kepala Madrasah yang belum diangkat sebagai pegawai negeri alias berstatus non PNS. Oleh karena itu kalau pemerintah tidak mampu membantu finansial secara rutin kepada Madrasah, namun setidaknya pemerintah dapat mengangkat kepala-kepala Madrasah yang statusnya bukan Pegawai Negeri Sipil (honorer) tersebut manjadi Pegawai Negeri Sipil. Dengan demikian mereka dapat bekerja dengan lebih tenang karena tidak lagi disibukkan dengan urusan memikirkan rendahnya pendapatan untuk dirinya serta lebih terjaminnya kepastian masa depan mereka (di hari tua) ketika sudah tidak lagi menjabat sebagai kepala sekolah.

\section{Kondisi Kepala Sekolah Berdasarkan Jenis Kelamin}

Data selengkapnya tentang kepala sekolah berdasarkan jenis kelamin adalah sebagai berikut (EMIS-DEPAG, Statistk Pendidikan Islam 2001 - 2002 : 48)

Tabel 2. Data Kepala Madrasah Berdasarkan Jennis Kelamin

\begin{tabular}{|l|c|c|c|}
\hline \multirow{2}{*}{ Jenis Madrasah } & \multicolumn{2}{|c|}{$\begin{array}{c}\text { Jenis Kelamin } \\
\text { Kepala Madrasah }\end{array}$} & \multirow{2}{*}{ Jumlah } \\
\cline { 2 - 3 } & Pria & Wanita & \\
\hline $\begin{array}{l}\text { Madrasah Ibtida'iyah } \\
\text { Negeri (MIN) }\end{array}$ & 1.141 & 341 & 1.482 \\
\hline $\begin{array}{l}\text { Madrasah Ibtida'iyah } \\
\text { Swasta (MIS) }\end{array}$ & 18.588 & 2.662 & 21.250 \\
\hline $\begin{array}{l}\text { Madrasah Tsanawiyah } \\
\text { Negeri (M Ts. N) }\end{array}$ & 1.084 & 81 & 1.165 \\
\hline $\begin{array}{l}\text { Madrasah Tsanawiyah } \\
\text { Swasta (M Ts. S) }\end{array}$ & 8.853 & 766 & 9.619 \\
\hline $\begin{array}{l}\text { Madrasah 'Aliyah } \\
\text { Negeri (MAN) }\end{array}$ & 553 & 24 & 577 \\
\hline $\begin{array}{l}\text { Madrasah 'Aliyah996 } \\
\text { Swasta (MAS) }\end{array}$ & 2.967 & 228 & 3.195 \\
\hline J u m I a h & 33.186 & 4.102 & 37.288 \\
\hline
\end{tabular}

Dari tabel 2 dapat diketahui bahwa mayoritas kepala Madrasah masih dipegang oleh kaum pria. Walaupun secara sepintas hal tersebut tidak jadi masalah, namun jika ditinjau dari kesetaraan gender, hal ini tentu merupakan masalah. Untuk mengetahui penyebabnya hal ini kiranya diperlukan adanya studi tersendiri.

\section{Kualifikasi Pendidikan Kepala Madrasah}

Sampai dengan tahun 1999, mayoritas
Kepala Madrasah Ibtida'iyah dan M.Ts. berpendidikan $\mathrm{D}_{3}$ atau kurang (Basic Education Proyek-Depag dan INSEP, "Bekerja Bersama Madrasah Membangun Model Pendidikan di Indonesia, 2002 : 42). Bagaimana kondisi tersebut setelah tahun 2002. Berikut data selengkapnya tentang pendidikan kepala Madrasah pada tahun pelajaran 2001/ 2002 (EMIS-DEPAG, Statistk Pendidikan Islam 2001 - 2002 : 49) 
Tabel 3. Kualifikasi Pendidikan Kepala Madrasah

\begin{tabular}{|c|c|c|c|c|c|c|c|}
\hline \multirow{2}{*}{$\begin{array}{c}\text { Jenis } \\
\text { Madrasah }\end{array}$} & \multicolumn{6}{|c|}{ Kualifikasi Pendidikan Kepala Madrasah } & \multirow{2}{*}{ Jumlah } \\
\hline & $<\mathrm{D} 2$ & $>=\mathrm{D} 2$ & $<\mathrm{D} 3$ & $>=$ D3 & $<\mathrm{S} 1$ & $>=S 1$ & \\
\hline MIN & 132 & 1.350 & - & - & - & - & \multirow{7}{*}{$\begin{array}{l}\text { Negeri: } \\
\text { 1. Memadahi } \\
=222 \\
\text { 2. Kurang } \\
\text { memadahi } \\
=3002 \\
\text { Swasta: } \\
\text { 1. Memadahi } \\
=12.006 \\
\text { 2. Kurang } \\
\text { memadahi } \\
=22.058\end{array}$} \\
\hline MIS & 8.510 & 12.740 & - & - & & & \\
\hline M Ts. N & - & - & 41 & 1.124 & & - & \\
\hline M Ts. S & - & - & 2.700 & 6.919 & - & - & \\
\hline MAN & - & - & - & - & 49 & 528 & \\
\hline MAS & - & - & - & - & 796 & 2.399 & \\
\hline Jumlah & 8.642 & 14.90 & 2.741 & 8.043 & 845 & 2.927 & \\
\hline
\end{tabular}

Berdasarkan tabel 3 diketahui bahwa masih ada sekitar 3002 kepala madrasah negeri dan 22.058 kepala madrasah swasta yang secara formal kualifikasi pendidikannya masih kurang memadahi. Hal ini tentu menjadi tugas pemerintah (Departemen Agama) untuk mengatasi masalah tersebut. Untuk itu perlu dicarikan terobosan-terobosan yang sifatnya innovatif agar para kepala Madrasah tersebut dapat melanjutkan pendidikannya sehingga mereka memperoleh kualifikasi pendidikan yang memadahi (minimal Jenjang S1 manajemen Pendidikan) dengan tanpa harus meninggalkan tempat tugasnya. Terobosan-terobosan tersebut misalnya memberi kesempatan kepada para kepala Madrasah untuk melanjutkan studinya di bidang Manajemen Pendidikan dengan melalui sistem pendidikan jarak jauh.

\section{Peran MDC (Madrasah Educations} Center) Madrasah Model, CLRC (Common Learning Resource Center) dan Departemen

Pendidikan Nasional Dalam Peningkatan Kualitas Kepala Madrasah

Dengan memperhatikan data tentang kondisi Kepala Madrasah seperti yang telah dikemukakan, maka di sana kita melihat adanya berbagai persoalan yang berkenaan dengan Kepala Madrasah seperti masih banyaknya kepala Madrasah yang berstatus honnorer, masalah gender, masalah kualifikasi pendidikan yang kurang memadahi dan lain-lain, maka perlu adanya intervensi dari berbagai pihak untuk mengatasi berbagai persoalan tersebut. Berbagai lembaga telah didirikan dan diharapkan dapat berperan dalam mengatasi berbagai persoalan yang dihadapi dalam pengembangan SDM Madrasah (khususnya Guru dan Kepala Sekolah) serta meningkatkan kualitas mereka, sehingga tujuan Madrasah yang ingin mendidik anak-anak bangsa menjadi manusia yang berkwalitas, islami dan mampu bersaing di pasar global dapat tercapai.

Berbagai lembaga tersebut antara lain MDC (Madrasah Educations Center), CLRC (Common Learning Resource Center), dan Madrasah Model. Tak lupa Departemen Pendidikan Nasional tentunya juga diharapkan peran sertanya dalam mengatasi persoalan tersebut.

\section{a. Peran MDC (Madrasah Educations Center)}

MDC atau Pusat Pengembangan Madrasah merupakan lembaga non struktural dan semi otonon yang berada langsung di bawah Ka Kanwil Depag merupakan lembaga yang tugas dan fungsinya menelorkan pemikiran-pemikiran innovatif untuk pengembangan Madrasah, MDC diharapkan dapat menyumbangkan berbagai pemikiran dan strategi untuk 
mengatasi persoalan-persoalan SDM di Madrasah khususnya guru dan kepala Madrasah.

Namun kenyataan di lapangan menunjukkan bahwa lembaga yang menjadi tempat berkumpulnya para pemikir Madrasah tersebut kebanyakan belum memulai aktivitasnya, meskipun fasilitas yang berupa gedung, mebelair dan peralatan kantor telah disediakan. Ada 2 MDC yang telah memulai aktivitasnya yaitu MDC untuk Propinsi Jawa Timur danSumatera Barat; namun di kedua MDC tersebut aktivitasnya belum menyentuh langsung pada persoalan Kepala Madrasah.

\section{b. Peran CLRC (Common Learning Resource Center)}

CLRC atau pusat sumber belajar bersama merupakan suatu lembaga yang dibentuk sebagai wadah bagi para guru Madrasah (termasuk kepala Madrasah) untuk meningkatkan kemampuan dan ketrampilannya. CLRC ini ditempatkan di Madrasah-Madrasah Model. Oleh karena itu pengelolaannya langsung berada di bawah Kepala Madrasah Model. Hampir seluruh CLRC telah melaksanakan programprogrammnya, namun kebanyakan program-program yang mereka laksanakan masih terfokus pada Guru, belum pada kepala-kepala Madrasah. Dengan demikian penataran-penataran, workshop maupun diskusi-diskusi yang mereka laksanakan pesertanya masih terbatas pada guru-guru Madrasah.

\section{c. Peran Madrasah Model}

Dari temuan di lapangan menunjukkan bahwa Kepala-Kepala Madrasah yang berhasil membawa Madrasahnya meraih sukses karena belajar dari teman-teman sesama kepala Madrasah yang telah berhasil meraih sukses terlebih dahulu.
Madrasah Model dibentuk untuk dijadikan model bagi madrasahmadrasah lain di sekitarnya guna ditiru keberhasilannya. Dengan kata lain keberhasilan Madrasah Model diharapkan dapat mengimbas ke Madrasah-Madrasah lain.

Meskipun keberhasilan seorang kepala Madrasah tidak harus dari Madrasah Model, akan tetapi penciptaan Madrasah Model lebih mengarah ke sana.

Yang menjadi persoalan buat Madrasah Model adalah ketika proyek sudah berakhir dan bantuan untuk Madrasah Model sudah tidak ada lagi, apakah Madrasah Model masih mampu mempertahankan predikatnya sebagai sekolah yang bisa dicontoh oleh MadrasahMadrasah lain.

\section{d. Peran Departemen Pendidikan Nasional (Depdiknas)}

Peran Depdiknas dalam meningkatkan kemampuan kepalakepala Madrasah berupa pemberian pelatihan-pelatihan di bidang Manajemen Pengelolaan Sekolah, namun karena pelatihannya masih menggunakan sistem konvensional, maka pelatihan tersebut belum mampu menjangkau seluruh Kepala Madrasah, terutama MadrasahMadrasah swasta yang berada di pelosok-pelosok dan daerah-daerah terpencil. Di samping itu, karena berbagai hal, pelatihan-pelatihan yang selama ini diberikan oleh Depdiknas sifatnya masih sporadis dan tidak berkelanjutan.

Untuk ini Depdiknas dapat mengambil iterobosan-terobosan yang sifatnya innovatif, misalnya memberikan pelatihan dengan menggunakan sistem belajar jarakjauh.

Ada beberapa keuntungan jika sistem ini yang dipilih. Keuntungankeuntungan tersebut antara lain : 
- Biayanya relatif murah,

- Depdiknas telah memiliki infrastruktur (Pustekkom, SEAMOLEC, Konsursium LPTK Penyelenggara PJJ, UT, PPPG Tertulis dan lain-lain)

- Pelatihan bersifat menyeluruh dan berkesinambungan, dan

- Para kepala Madrasah dapat mengikuti Pendidikan ataupun pelatihan dengan tanpa harus meninggalkan tempat tugasnya.

\section{Berbagai Isu dan Masalah Sehubungan dengan Desentralisasi}

Sehubungan dengan rencana akan didesentralisasikannya Madrasah, untuk Kepala Madrasah-Madrasah Swasta tidak ada masalah karena bagi mereka sama saja antara sentralisasi dengan desentralisasi. Untuk Kepala Madrasah Negeri, umumnya mereka tidak tahu menahu tentang soal tersebut, karena selama ini mereka memang tidak pernah memperoleh informasi tentang hal tersebut. Setahu mereka Madrasah akan tetap dikelola oleh Pusat.

Permasalahan justru muncul dari kalangan pejabat Depag daerah (Kanwil Depag dan Kandepag). Mereka nampaknya menghendaki agar desentralisasi Madrasah jangan dilakukan dengan tergesa-gesa. $\mathrm{Hal}$ ini mereka kemukakan berdasarkan pengalaman desentralisasi yang telah dilakukan terhadap'sekolah-sekolah yang dikelola oleh Depdiknas, ternyata hasinya tidak seperti yang diharapkan, bahkan cenderung kurang menguntungkan. Isu lain yang dikemukakan oleh wakil dari Kantor Dinas Pendidikan Nasional Propinsi mengatakan bahwa kini Dinas Pendidikan Propinsi sulit melakukan kontrol terhadap sekolah-sekolah yang telah didesentralisasikan. Oleh karena itu mereka tidak menghendaki jika hal itu juga terjadi di Madrasah.

\section{KESIMPULAN DAN SARAN}

\section{Kesimpulan}

Dari hasil kajian dapat dikemukakan beberapa kesimpulan sebagai berikut:

a. Dari segi status kepegawaian, Kepala Madrasah yang belum diangkat menjadi pegwai negeri jumlahnya lebih banyak dari Kepala Madrasah yang telah berstatus sebagai pegawai negeri.

b. Dari segi segi jenis kelamin, mayoritas Kepala Madrasah adalah pria.

c. Dari segi kualifikasi pendidikan, sebagian besar Kepala Madrasah belum memiliki kualifikasi pendidikan minimal S1 Manajemen Pendidikan.

d. Hubungan antara Kepala Madrasah dengan siswa-siswanya dan juga dengan para orang siswa relatif bagus, kondusif dan mendukung perkembangan Madrasah.

\section{Saran}

a. Dengan diberlakukannya UndangUndang Nomor 20 tahun 2003 tentang Sistem Pendidikan Nasional, dan akan diberlakukannya UndangUndang Nomor 14 tahun 2005 tentang Guru dan Dosen serta Peraturan Pemerintah Republik Indonesia Nomor 19 tahun 2005 tentang Standar Nasional Pendidikan mak Baik kuantitas maupun kualitas Kepala Madrasah perlu ditingkatkan.

b. Mengingat Madrasah sudah menjadi satu kesatuan dari sistem pendidikan Nasional, maka pihak Departemen Pendidikan Nasional perlu meningkatkan perannya dalam ikut serta meningkatkan kualitas KepalaKepala Madrasah. Untuk kepentingan ini Depdiknas hendaknya bekerja sama dengan Departemen Agama.

c. Mengingat lembaga pendidikan yang menerapkan sistem pendidikan secara konvensional (tatap muka) masih memiliki keterbatasan daya jangkau, artinya belum mampu menjangkau guru-guru Madrasah yang tersebar ke segala penjuru pelosok tanah air, maka pemerintah perlu memikirkan sistem lain yang 
bersifat innovatif yang dapat mengatasi kendala waktu dan tempat yaitu sistem pendidikan terbuka dan jarak jauh bagi peningkatan kualitas Kepala Madrasah.

\section{REFERENSI}

Departemen Pendidikan Nasional RI, "Peraturan Pemerintah Republik Indonesia Nomor 19 Tahun 2005 tentang Standar Nasional, Jakarta, 2005

"Undang-Undang Republik Indonesia Nomor 14 Tahun 2003 tentang Sistm Pendidikan Nasional, Jakarta, 2003 "Undang-Undang Republik Indonesia Nomor 20 Tahun 2005 tentang Guru dan Dosen, Jakarta, 2005

Education Management Information System (EMIS), Statistik Pendidikan Islam MI, MTs.dan MA Tahun Pelajaran 1998/1999 sampai dengan tahun Pelajaran 2001/2002, Ditjen Baga Islam Departemen Agama , Jakarta, 2002.

Leaflet Pendidikan Islam Madrasah 'Aliyah tahun 2001/2002, Ditjen Baga Islam Departemen Agama, Jakarta, 2002.

, Leaflet Pendidikan Islam Madrasah 'Ibtida'iyah tahun 2001/2002, Ditjen Baga Islam Departemen Agama, Jakarta, 2002.
Leaflet Pendidikan Islam Madrasah Tsanawiyah 2001/2002, Ditjen Baga Islam Departemen Agama, Jakarta, 2002.

Directorate General Of Islamic Institution Development-Ministry of Religious Affair, "Studes On Madrasah Education Sub-Sector Assesment On Development Madrasah", PT Amythas Experts And Associates, Jakarta, 2003.

Indradjati Sidi, Tenaga Kependidikan dan Permasalahannya, Direktorat Jendral Pendidikan Dasar dan Menengah, Jakarta, 1999.

Kelompok Kerja Tenaga Kependidikan, Rekomendasi-Rekomendasi Untuk Pemberdayaan Guru dan tenaga Kependidikan, Badan Perencanaan Pembangunan Nasional Biro Agama, Pendidikan, Kebudayaan, dan Olahraga, Jakarta, 1999.

Pusat Studi Pengembangan Islam dan Masyarakat UIN Syarif Hidayatullah: "Journal Madrasah 1996", Jakarta 1996.

Saiful Umam dan Arief Subhan, Bekerja Bersama Madrasah Membangun Model Pendidikan Indonesia, Basic Education Project (BEP) Departemen Agama RI dan Indonesian Institute For Society Epowerment (INSEP), Jakarta, 2001

Waldopo, Anung Haryono dan Suharto Lasmono, Pendidikan Jarak Jauh Pustekkom Depdiknas, 2008. 